\title{
Exploring the right to mobility through the 2013 mobilizations in Rio de Janeiro
}

\section{Abstract}

In this paper we explore the unfolding of the right to the city through a focus on urban mobility. We analyse the way urban social movements (USMs), which play a crucial role in shaping the right to the city, frame their struggles in relation to mobility. We argue that their use of the concept of the 'right to mobility' has two meanings. First, the concept gives USMs a framing discourse to advocate and shape transport policy changes. Second, it enables USMs to bring together different actors with different urban agendas. We base this argument on a study of Rio de Janeiro, a paradigmatic case of mobility-based claims of the right to the city. Looking at the practice of a protest-oriented and a knowledge-oriented USMs that contest this mobility crisis, we outline an agenda for academics and practitioners willing to work towards the construction of sustainable and just mobilities.

\section{Introduction}

In June-July 2013 Brazil was shocked by a wave of intense mobilizations with millions of people in the streets (Maricato et al. 2013; Cava 2013; Cava and Cocco 2014; Jennings et al. 2014). Begun as protest to an increase in the public transport fare, these mobilizations quickly expanded their claims to contest the entire mobility system and model of urban development. There have been claims for cheaper and higher quality public transport, and at the same time critiques of investments planned for the mega-events, making a strong case against the governance of mobility and public services highly involved in financial scandals. These protests merged long-lasting work of grassroots and activist in the city (Cava 2013; Fernandes and Freitas Roseno 2013; Nobre 2013; Judensnaider et al. 2013), who have been framing their struggle increasingly around the idea of the 'right to the city' and 'the right to mobility'.

Rio de Janeiro, city in which the 2013 mobilizations took place on an exceptional scale, represents an optimal case study to investigate urban contestation and the right to mobility in the Latin American context. As both a city and region, Rio de Janeiro has faced a particularly sharp mobility crisis for many years. With the broad aim to contribute to the understanding of contested mobilities, this paper looks at the way Rio de Janeiro's urban social movements (USMs), a key if understudied actor in urban mobility politics, engage in contestation in the mobility realm. We argue that a key way of seeing USMs' engagement is through a dual use of the concept of 'right to mobility'. First, the concept gives USMs a framing discourse to advocate and shape transport policy changes, and second, it enables them to bring together different actors with different urban agendas.

Specifically, this paper analyses two USMs from Rio de Janeiro, the Forum de Lutas and the Mobility Forum, that, with different strategies of protest-oriented and knowledge-oriented, played a key role in the 2013 mobilizations and in the general contestation of transport interventions and policies in the city. Focusing on how they frame and use the concept of the right to mobility, we aim to broaden the debate on the right to mobility, and to more strongly assert the role of USMs as actors of change into the transport geography literature.

The paper is based on the data collected during twelve months of fieldwork in Rio de Janeiro (Venturini 2016; Verlinghieri 2016), using qualitative methods and inspired by an action research approach (Fals-Borda and Rahman 1991; McTaggart 1997; Breitbart 2003; Coghlan and Brannick 2005; The Autonomous Geographies Collective 2010) and the need to decolonize knowledge (Chakrabarty 2008; Sheppard et al. 2013; Smith 2013; Venturini 2016). Specifically, the data on which we rely upon are our fieldwork notes, 29 semi-structured interviews conducted with the members of the two USMs and local transport practitioners, and original documentation produced by the USMs themselves. 
The paper is structured in four parts. Drawing from Lefebvre's work, we firstly introduce the concept of the right to the city. We then discuss the right to mobility as a functional part and distinctive aspect of the right to the city. We use the term 'mobility' referring to people's mobility in the urban realm. We embrace elements of both the classical transport studies and the mobilities traditions, aware of the importance of accounting for all of the spatial, physical and governance elements of the transport system and mobilities. We explore the potential for the right to mobility to enrich the analysis proposed by the right to the city on the production and reproduction of urban inequalities. We then analyse the discourses and practices of the Forum de Lutas and the Mobility Forum, two USMs working on transport and mobilities issues in the contested city of Rio de Janeiro. From this analysis we draw important learning points for transport policy and practice. Specifically we highlight the role of the right to mobility, and especially of the 'right to sustainable and just mobility' in bringing together different actors, politicising and broadening the potential of transport policy and practice towards more sustainable futures.

\subsection{The right to the city and the right to mobility}

The right to the city was first introduced by Lefebvre in 1968, and the concept is used widely in academic literature and by a variety of institutional and grassroots actors. It has assumed growing importance in the urban agenda, informing planning literature and discourses on democracy and citizenship (Purcell 2002; UNDP 2010). However, despite a vast literature on the right to the city, there is still a limited use of the concept in transport geography (e.g. Attoh 2011, 2012; Legroux 2013, 2014, 2016; Sagaris 2014).

For Lefebvre, "the right to the city is like a cry and a demand" (1996: 158). It is the compelling expression of the necessity to overcome current urban inequalities, allowing all citizens to fulfil their needs and hopes; it is an aspiration for change (Marcuse 2012). While Lefebvre does not give a full definition of the term (Souza 2010; Attoh 2011), the right to the city can be framed in terms of the right to appropriation and right to participation. The former refers to the physical access and use of the urban space and the latter the ability to politically shape urban futures (Purcell 2002). The right to the city is the right to full and equal enjoyment of the resources and services concentrated in cities. More than that, it is a call for empowerment of urban marginalised into decision-making. It refers to the possibility for people to shape their own city trough selfmanagement (Lefebvre 1996). For Harvey (2008), the right to the city is "the freedom to make and remake our cities and ourselves" (23), with a clear emphasis on the collective aspect of this right. The call for the right to the city comes from the "most marginalized and the most underpaid and insecure members of the working class" (Marcuse 2012: 32) as well as from all the citizens directly oppressed and alienated by the dominating urban project.

The concept of the right to mobility has been more recently introduced within the mobilities tradition (Cresswell 2006; Pécoud and De Guchteneire 2006; Hague 2010; Wellman and Cole 2011) ${ }^{1}$. As considered by Sheller (2008), it refers to access to the city and is connected to the idea of making of citizens, subjects, and bodies, who are often limited by borders, controls, policing, regulation of public space, to the even or uneven distribution of ease and safety, and uneven terrains for movement of speed and governmentality (Sheller and Urry 2006). The right to mobility can be considered as expressing the right to move in the urban space, to access places and opportunities, but also the right to move or stay still. Moreover, considering the embeddedness of individual mobility choices with societal needs, the right to mobility can be approached as a collective right (Sager 2006).

A connection exists between the right to mobility and the right to the city. For example, Attoh (2012) considers:

\footnotetext{
${ }^{1}$ These authors often associate the right to mobility with the human right of free movement between different countries. In this paper, recognising the importance of supporting the universal recognition of the right to mobility, we, however, consider it only within the urban and peri-urban context.
} 
"The right to the city exists simultaneously as a right to access public space, a right to access socioeconomic goods like housing, a right to organize collectively, and a fundamental right of the poor and marginalized to produce a more just city" (5).

In this definition the right to the city includes the right to go to school, to go to the hospital, to access culture, social networks, places of decision-making. This 'getting to' the city is made possible only by the fulfilment of the right to mobility in the urban space. If we acknowledge that mobilities have a dual relationship with society, shaping societal processes and being shaped by them (Pucher and Lefèvre 1996; Vasconcellos 2001; Hickman and Banister 2014), a dual relationship can also be highlighted between the two concepts. On one hand, the right to mobility is functional part of the right to the city, being a necessary condition for both the right to appropriation and the right to participation to be met. As such, there is an overlap between the right to mobility and the need to ensure a purposeful movement to access services, social capital, and the city (Ferreira and Batey 2007). The right to mobility subsumes also the right to accessibility, as fundamentally linked to questions of just access to resources and assets. On the other hand, the right to mobility goes beyond and enriches the perspective given by the right to the city bringing the attention to the key role of mobilities in the production of urban processes (Hannam et al. 2006; Sheller 2011).

\subsection{Building the right to mobility: the role of USMs}

$\mathrm{USMs}^{2}$ are crucial actors when considering the demand for and the building of the right to the city (Mayer 2000; Brenner et al. 2012) and, as we argue in this paper, the right to mobility. USMs constantly claim these rights as part of their demanding equal access to services and urban decision-making (Hamel et al. 2000) and gain strength from them (Souza 2006a; Vradis 2012). At the same time, as political actors able to destabilise existing meanings and produce concrete alternatives, USMs contributed to the definition of the right to the city and can help to better understand also the right to mobility. With their perspectives and practices USMs can assume the role of 'activist' planners (Miraftab 2009; Sager 2016), able to produce "substantial input to plans, alternatives to official planning proposals and ideas about desired urban development" (Sager 2016: 1264) contesting and shaping urban processes both as outsiders and insiders to the planning system (Souza 2006b).

For these reasons, the transport literature has suggested focusing on USMs as actors of change, especially in the transition towards sustainability (Vasconcellos 2001; Geels 2010; Schwanen et al. 2011). USMs can influence institutional planning, as well public behaviours, attitudes and practices. They are "essential seeds of transformations" (DeVerteuil and Golubchikov 2016: 148), as they demonstrated in bringing to public attention the environmental impacts of transportation choices, opposing automobility since the 1980s (Rawcliffe 1995; Vigar 2013). At the same time, USMs have an active role in stressing the difficult urban mobility conditions of the disadvantaged, demanding interventions and affecting in the long-term politics of transport. Especially in the Latin American context, they have a long history of contesting the malfunctioning of transport systems and claiming for the right to mobility (Vasconcellos 2001).

However, only few authors have considered in depth the contribution by USMs focused on transport and mobilities. For example, Rawcliffe (1995) traces the history of UK environmental movements till the 1990s

\footnotetext{
${ }^{2}$ We are aware that USMs is a wide category to be considered. Schuurman (1989) defines USMs as "a social organization with a territorial based identity, which strives for emancipation by way of collective action" (9). USMs as able to build a critical mass (Mayer 2000) towards social change (Castells 1977, 1983; Souza 2006b; Mayer 2012, 2013). Despite certain authors define as USMs actors with an explicit anti-capitalist position, for Mayer (2006) and Castells (2012), USMs include all the groups able to reshape society and contest the city as it is presently, avoiding a Right/Left wing distinction. In this paper we adopted the Mayer (2006) and Castells (2012) connotation, to indicate the actors that the transport literature has suggested to interrogate for new visions and practices on planning. This definition allows leaving open a broad spectrum of actors to be taken into consideration, including also those that rely less on protesting and 'performance' acts (Juris and Pleyers 2009) and are more focussed on knowledge production, that we call knowledge-oriented actors.
} 
highlighting the way it has strongly embraced a no-road-building position. This is one of the few academic pieces to fully concentrate on the role of USMs in making the transport policy community more sensitive to environmental arguments and to the voices of community actors. In the Latin American context, Sagaris (2014) focuses on community groups and USMs as transport policy actors, following the development of the 'Living City' initiative in Santiago de Chile as anti-road movement able to challenge planning paradigms and creating citizen-led planning institutions. On a more theoretical line, Paterson (2007) in his account of the political economy of automobility analyses the role of pro and anti-car movements. A bigger number of studies, mostly concerned with the Anglo-Saxon world, focus on cycling-related activism, considering the way USMs frame questions of cycling identity and politics (Aldred 2013), its ability to shape green lifestyles and environmental movements (Horton 2006), and the transformative power of biking (Furness 2010). Specifically significant is the contribution of Furness (2010) in its acknowledging the connection of the bike advocacy movement with the claim for a 'right to the city'.

These papers constitute a starting point for a needed account and analysis of the role of USMs as planning actors for transport. However, they only partially provide a geographical analysis of USMs' contributions and limitedly connect them to the right to the city agenda. The theoretical formulation proposed in this paper, together with the insights from two highly meaningful case studies from the contested city of Rio de Janeiro, address this literature gap. We highlight the importance of focussing on USMs as actors that shape the politics of mobility and that provide and original formulation of the 'right to mobility'. Moreover, we present evidence to make a strong connection between the right to mobility and the right to the city and important indications of how to use these concepts as tools to guide transport planning. We also highlight the role of mobility in shaping the urban crisis.

\section{Case study: Rio de Janeiro}

Figure 1: Rio de Janeiro and its metropolitan region (Fundação CIDE nd: np)

The city of Rio de Janeiro is the capital of the State of Rio de Janeiro (in brown in Figure 1) and the core of the Rio de Janeiro metropolitan region, visible in Figure 1, whose extension is of 4,539.8 Km2 with over 12 million inhabitants. The city and the Region represent one of the most interesting cases in Latin America of fast regeneration and infrastructural development. After a period of decline in the 1980s, since the 2000s they entered a new period of expansion and economic growth connected to industry and logistic services (Palladini 2011). This growth has been boosted by the investment made for mega-events such as the 2014 FIFA World Cup and 2016 Olympic Games (Sistema FIRJAN 2012, 2014). Specifically, the city has faced deep and rapid transformations, with an overarching vision of becoming a competitive, world-leading attraction for investments and tourism (Rio 2016 2014). The city has attracted national and international capital thanks to the promotion of Public-Private Partnerships (PPP) and the adoption of a strategic planning strategy inspired to the Barcelona Model (Vainer 2000a; González 2011; Pontes 2013). In particular, in view of the mega-events, the city has undertaken major changes in its transport infrastructure. These are part of a Program for Sustainability and Environment aiming at guaranteeing low environmental impacts and conservation of the natural patrimony, while attention is given to the provision of public services and facilities (Rio 2016 2014).

The benefits of this rapid economic development, that can be inscribed in an overarching project of neoliberal urbanism (González 2011) and urban entrepreneurship (Harvey 1989, 2001; Hall 1992, 2006), have been unequally distributed among the population (Comitê Popular 2012-2016). Rio de Janeiro has the largest favela population in Brazil (1.3 million people) and its population landscape still projects patterns of profound inequality and segregation among social classes (Souza 2008; Perlman 1979, 2010). Moreover, it is a city that experiences important phenomena of socio-spatial fragmentation (Souza 1999, 2001b, 2008), with exceptional levels of urban poverty and injustice (Pontes 2013; Alencar 2013) and urban violence (Souza 2008). Researchers have shown that the process of commodification of the public space through large 
privatization and PPP investment has exacerbated these phenomena (Freeman 2012; Pires 2013). Furthermore, it has additionally generated patterns of periferization and reduced access to public infrastructures for the urban poor that have extended geographical exclusion and loss of spatial capital (Souza 1999). For Vainer (2000b, 2013a) the state of emergency regulation implemented for the megaevents has negatively impacted also citizens' ability to participate in public life, being the normal democratic structures weakened (Gaffney 2010) in the creation of a 'city of exception' (Vainer 2013a). Similarly, according with the analysis provided by Purcell (2006), the use of PPPs has negatively impacted the normal democratic decision-making.

\subsection{Mobilities in Rio de Janeiro}

Figure 2: the State of Rio de Janeiro and its public transport system (Dörrbecker 2016: np)

Since the 2010s Rio de Janeiro has undertaken major investments to improve its urban transport infrastructure, amounting at US\$2.8 billion for the period 2012-2014³ (Sistema FIRJAN 2012). Specifically, the Transport Planning Strategy approved within the Olympic bid has aimed to implement a High Performance Transport Ring connecting all the Olympic zones (Rio 2016 2009; Silva and Torres 2013). As visible in Figure 2, which depicts the public transport system in 2016, main infrastructural works have been implemented at the metropolitan level, and integrated with the main Olympic attractions (labelled in brown): the Metro Line 4, four new BRT lines, the renovation of the rail system, the development of the International Airport and the Port, the expansion of the road network, the construction of three new cableways, and a light rail vehicle. These new infrastructures complement the existing transport system composed of two Metro lines, a network of suburban trains, and numerous bus services. With the new investments, high importance has been given to the improvement of public transport facilities that represent the main transport mean, in a city in which the majority of the population (75\% in 2009) relies on public transport, mostly on city-busses with demand for public transport on rail steadily increasing (Secretaria de Estado de Transportes 2014).

Despite these investments, mobility in the metropolitan region of Rio de Janeiro still relies mainly on road transport, specifically on buses/BRTs and private cars, and road transport has remained the place where the core of the investment has been concentrated since the 1920s. In this system, the citizen dissatisfaction with transportation is mainly connected with congestion, safety, and cost of public transport (Cava 2013). The literature shows also the important social impacts of the mobility model adopted. Specifically, referring to the classification of social impact proposed by Jones and Lucas (2012) there can be individuated impacts in terms of accessibility, health-related, financial-related, and community-related impacts.

Especially in terms of accessibility, the differential mobilities patterns in the city determine sharp differences across social groups (Jones and Lucas 2012). In a city of sharply differentiated spatial distribution of residences, services, amenities, workplaces, and infrastructures, Pires (2013) and Vasconcellos (2014) speak of 'excluding mobility'. Issues are present both in terms of available infrastructures and in terms of management of the existing ones (Pontes 2013), together with the lack of planning and investments in public transportation, especially in a context of quickly expanding peripheries (Rodrigues 2014). Low-income groups generally rely on walking, biking ${ }^{4}$ and buses, and find it difficult to access cars, which is the mode for which the transport system is mainly designed for. Many of them are also deprived of access to collective transport (Avila 2006). This results in important patterns of differential mobilities (Pero and Mihessen 2013; Pereira and Schwanen 2013) in a city where commuting requires an average of $55 \mathrm{~min}$ by public transportation against 34 min by private vehicle, due to the large commuting distances, poor infrastructures, and high congestion (caused by the high number of private vehicles and lack of segregated bus lanes). In

\footnotetext{
${ }^{3}$ Amount invested for the Metro Line 4 and the Metropolitan Ring Road

${ }^{4}$ In 2008 , approximately $30 \%$ of the poorest people in Rio ( $5^{\text {th }}$ income quintile) commuted to work walking or by bike (Sá et al. 2016).
} 
2008 a survey showed that people in the region spend $22 \%$ of their daily time on transportation ( 86 min per day) (IBGE 2008).

The health-related impacts of the transport system in place, especially in terms of car incidents and transportrelated deaths are also high (Costa et al. 2013; Maricato 2015). Moreover, there is a high incidence of transport poverty ${ }^{5}$ in the region (Pero and Mihessen 2013): whilst the quality of public transport is below the expected standards, with very poor intermodal integration, families spend a significant portion of their incomes on transportation (Rodrigues 2014). This is dramatic for lower income groups. For example, at the end of the 2010, families in Rio de Janeiro were spending 19.8\% of their income on transportation, whilst data from 2003 showed that $35 \%$ of population cannot afford to pay a bus fare (Carvalho and Pereira 2012).

Finally, community-related impacts are specifically sharp as a consequence of the implementation of new infrastructures that often generate segregation processes and forced residential relocation (Comitê Popular 2012-2015; IPPUR/UFRJ 2012; Legroux 2013, 2014, 2016; Santos Junior et al. 2015). For example, the implementation of the different transport-related infrastructures has required the relocation of a total of 2,125 families from poor settlements (most of which legally set up) (Prefeitura do Rio 2015). Since 2008, public policies on housing, security, and public transport have been part of a process of commodification of the public space that resulted in important phenomena of gentrification and consequent removals (Pires 2013; Assis 2014; González 2016). Forced to relocate, lower income groups have experienced increased accessibility issues and decreasing social capital.

All these aspects contribute to build what various scholars call an 'urban mobility crisis' in the metropolitan area of Rio de Janeiro (Rodrigues 2014; Legroux 2014; Costa et al. 2013; Maricato 2015). This crisis, for Beyer (2011), "leads to a growing physical fragmentation (by saturation) and social (by the unequal distribution of accessibility)" (8), generating sharp distributional effects and social justice issues (Jones and Lucas 2012) and social vulnerability (Pontes 2013).

\section{Protest-oriented and knowledge-oriented movements}

USMs can apply different strategies to claim their demands, which can be more or less confrontational or collaborative (Pickvance 1977; Harvey 2001; Mayer 2006). There is a recognised tendency to work "within and outside institutions - with a focus on challenging prevailing forms of decision and policy making" (Mayer 2000: 139), in a way that Souza (2006b) calls "together with the state, despite the state, against the state" (327). Specifically, a distinction can be made between 'protest-oriented' and 'knowledge-oriented' movements ${ }^{6}$. Protest-oriented movements consider direct action and street protests feasible strategies for reaching their goals. Knowledge-oriented movements are focused on knowledge production; they do not consider street action as main strategy, but do not exclude it as a possibility ${ }^{7}$.

In the context of Rio de Janeiro, the protest-oriented movements have been at the core of the 2013 upraises, building an important network of activist planning actors (Sager 2016) with different levels of insurgency (Holston 1998, 2008, 2009). They can be inscribed in a historic worldwide tradition of popular movements against highway constructions (Zibechi 2012). Among them, the Movimento Passe Livre - Free Pass Movement (MPL) had an important role in bringing transport issues in the public domain and ignited the street protests. Amongst knowledge-oriented movement counts a variety of pressure groups, such as the one reported in Table 1, concentrated in contesting specific projects.

\footnotetext{
${ }^{5}$ We refer to the definition of transport poverty provided by Lucas et al. (2016), in which transport poverty is the result of the overarching combination of transport affordability, mobility and accessibility poverty, and exposure to transport externalities. ${ }^{6}$ A similar distinction is proposed by Vasconcellos (2001) that distinguishes between open and hidden social movements. ${ }^{7}$ Specifically with regard to knowledge-oriented actors, despite their practices might be seen as overlapping with think-thank or lobbying ones, our term stresses their different aspects of commitment to social change, not being institutionalised as organizations and not receiving funding from other bodies.
} 
Table 1: Pressure Groups Relating to the Olympic Games and their Means of Action in Rio de Janeiro (adapted from: OGI - SAGE/COPPE/UFRJ Research Team (2014: 101))

In the following sections we show how these different USMs conceptualise the right to mobility analysing two examples from Rio de Janeiro with whom we collaborated during our fieldworks: the Forum de Lutas and the Mobility Forum. These two actors are the main representatives of the two aforementioned USMs approaches in the city. Specifically, as forums they include and represent a variety of other actors; most importantly, they have been the most numerous movements working on transport and mobility issues in the city during the period analysed in the paper.

\subsection{Protest-oriented: the Forum de Lutas}

The Fórum de Lutas contra o aumento da passagem - Forum for the struggle against increase of transport price $^{8}$ (Forum de Lutas) has been a key actor in initiating mobilizations in Rio de Janeiro since 2013 and a crucial protest-oriented actor in the city claiming for the right to mobility. Created in October 2012, it was formed by various collectives, groups and political parties from the Left. It is an example of non-hierarchical mode of organization that works as a network in recruitment processes (Della Porta and Diani 2006) and that reaches a bigger audience than the participants in its meetings. Despite all the decisions in the Forum de Lutas were taken by majority after discussions in the assembly, different tendencies collided on this point. With the growing influence of political parties and increasing internal political differences, the Forum de Lutas ceased to function in summer 2014. Main activities of the Forum de Lutas were public assemblies and social mobilizations and it was financed through donations by its members.

Since its inception the Forum de Lutas placed the neoliberal city at the centre of its critique, focussing on transport issues as the expression of the crisis in this model of city most in need to be addressed. The starting point of this contestation was the rise of bus fares and the demand for a better transport system, as fundamental aspects of people's livelihoods. The mobilizations organised by the Forum de Lutas managed to block the ticket-price increase and forced the City Council to open an investigation regarding the process for establishing the tariff (CPI dos Ônibus nd). However, people mobilised in the street were shouting, "It is not just for 20 cents!" (20 cents being the ticket price increment). Interpreting popular discourses, the Forum de Lutas saw the transport issues as deeply linked with the unequal urban configuration. Around mid-July 2013 the demands of the Forum de Lutas started concentrating not only on claiming for a better and cheaper transport system, but included the end to the military police and repression, more investments for education and health systems rather than for mega-events; the end of favela evictions; the democratization of the media. Finally, also the right to the city was explicitly added as a goal of the group?.

In terms of mobility, the Forum de Lutas contested not only the price of transport and its low quality, but also the related spatial segregation. The quality of public transport was its concern in a dispute in which the idea of comfort of transport was proposed as a fundamental aspect of quality of life. The malfunctioning nature and unsafeness of the system was also connected to the exploitation of workers, forced to work at the same time as drivers and ticket sellers, and to the so called bus companies 'mafia'" ${ }^{10}$. The ticket increase was compared by the Forum de Lutas and the street mobilizations to robbery: considered small by the planning

\footnotetext{
${ }^{8}$ More information at: https://www.facebook.com/forumcontraoaumento and http://forumdelutasrj.blogspot.com.br/

${ }^{9}$ It would be hard to trace the first use of the concept of the right to the city by the Forum de Lutas and how/by who it has been introduced. However, we can state that it was not introduced by academic scholars, being a term of already common use by USMs in Rio de Janeiro and included in the City Statute exactly as result of USMs demands (Friendly 2013).

${ }^{10}$ In Rio de Janeiro the public transport service of the city was outsourced in 2010 to four consortia (composed of more than 40 companies), in a system that appeared not clear also to the Court of the City that questioned it, founding "strong evidence of a formation of a cartel" (Tribunal de Contas do Município 2012: 8). USMs, as well as the broader society, started to speak about a 'bus mafia': four owners of companies account for nearly a third of all shares in the four winning consortia (Magalhães and Berta 2013). The pressure generated by the mobilizations and the rising public attention on public transport issues forced the City Council to open an investigation in August 2013.
} 
authorities, the increase has had a great impact on the poor population whose daily livelihoods depend on public transportation (Carvalho and Pereira 2011). Figure 3 shows placards photographed on demonstrations promoted by the Forum de Lutas that stress the dramatic effects of the ticket increase. Two banners report: "How much does it cost, the right to come and go?" and "Public transport is not a commodity". Both put strong emphasis on the commodification of what is perceived to be a fundamental right: the right to ir e vir come and go in the city. This right has been severely damaged by a very expensive, low quality transport system that reinforces spatial-social segregation.

Figure 3: Placards during a demonstration (photo by Federico Venturini)

USMs in Brazil have a long tradition of fights around the right to the city conceived as the right to housing for the poor (Souza 2001a, 2001c). However, in June 2013 the struggle was mainly around the right to ir e vir for the excluded population. This is the term that the Forum de Lutas and the other USMs use to articulate what we call the right to mobility. The claim for the right to ir e vir was expressed directly with the demand for the withdrawal of the ticket price increase as 'right to affordable public transport', but also with a broader agenda that asked for better public transport conditions. Solutions proposed were improved services and the tarifa zero - zero fare ${ }^{11}$. For the Forum de Luta, as part of guaranteeing the right to ir e vir, transportation should not be seen only as a means to get to work, but as a fundamental mean for life in the city. In this are included all the aspects of urban living that lowest income group have not guaranteed, in a city of sharp inequalities.

\section{Figure 4. Sticker by the Forum de Lutas (photo by Federico Venturini)}

This is evident in the sticker, circulated by the Forum de Lutas and stuck in support of the campaign all around the city and inside the public transport, reported in Figure 4, "Zero fares: for the right to the city". The sticker makes a clear connection between the right to ir e vir and the right to the city. For example, as one activist told us, the scarcity of transport options does not take into account that people "do have the right to have fun". This needs to be intended as part of the aforementioned debate on transport as a mean to guarantee quality of life, beyond pure access to work-place. As another activist told us, the mobilization addressed mobility issues and the right to ir e vir as part of a larger problem:

"Urban mobility and transport are part of a context of a much larger plan, it is part of a much larger context of a city. [...] You need to have urban mobility, you also need to have a good quality of life, good public services."

To confirm this point, all our interviewees reported how the increase of the ticket fare was only the straw that broke the camel's back, opening a debate on wider requests for right to the city and spatial justice.

In the specific case of Rio de Janeiro, transportation issues are also strongly connected with mega-events and the resulting neoliberalization of the urban. As stressed by the Forum de Lutas, the new transport infrastructures built for mega-events have sharply increased transport injustices. One of the members of the Forum de Lutas, said us: "[the investments] serve the FIFA World Cup and the flow of people that the FIFA World Cup will bring and not the needs of the population". Similar discourses emerged in relation to infrastructures for Olympic Games, such as a BRT aimed at only connecting the airport with the Olympic facilities. In the Forum de Lutas' view, the new infrastructures failed to satisfy the mobility needs of the population, reproducing spatial injustice and exacerbating the mobility problems of people evicted, displaced from the city centre and not served by transport infrastructures (Legroux 2013). Ultimately, as another member of the Forum de Lutas said us, as result of the politics of mobility in place, poor people "have no

\footnotetext{
${ }^{11}$ The zero-fare public transport is a project, implemented in a few cities in Brazil, in which public transport is funded in full by means other than collecting fares from passengers (Tarifa Zero 2011).
} 
right to use the city that they help to build".

\subsection{Knowledge-oriented: the Mobility Forum}

The Fórum Permanente da Mobilidade Urbana na Região Metropolitana do Rio de Janeiro - the Permanent Urban Mobility Forum of the Metropolitan Region of Rio de Janeiro (Mobility Forum) is a forum composed by transport engineers, representatives of Residents' Associations, professional councils, unions, various institutions, NGOs and citizens that weekly meet to discuss mobility issues within the Rio de Janeiro metropolitan region. The Mobility Forum was born in 2011 within the Rio de Janeiro Engineering Club under the assumption that "society is willing to propose new directions for transport and mobility" (Clube de Engenharia 2014). It emerged in response to the need of the engineers to open up their horizons and proposing of solutions to the mobility crisis with the contribution of popular knowledges and in direct contact with the population. One of the engineers member of the Mobility Forum that we interviewed, stated:

"The Mobility Forum was born because we had only technicians and discussing only among technicians produces nothing. Now, when you have the participation of society, of social movements, it adds a value".

The Mobility Forum has been founded seeking collaboration between engineers and social actors to produce new answers to the mobility crisis. The Mobility Forum lacks a formal structure and is managed by two coordinators, an engineer and a member of the residents associations. In 2014 it counted more than 300 members in a network of associations, NGOs, and USMs. They meet weekly "to discuss and listen to the civil society on issues of mobility and its modes, in addition to developing diagnostic and technical discussions on public policy in this sector" (Fonseca 2016). In this way the Mobility Forum aims to provide information and research instruments to community groups, USMs, and disadvantaged groups to understand mobility issues or to facilitate their actions aimed at achieving a better and more just transport system. In its manifesto the Mobility Forum explicitly refers to the right to mobility, aiming to be:

"Committed to society, to fight for the guarantee of the Article5, XV of the Constitution: "movement within the national territory in time of peace is free, and any person, under the law, can enter it, remain or leave it with his/her assets"” (Fórum Permanente 2011: np).

The Mobility Forum works in order for the constitutional right to mobility to be respected and guaranteed in the region. In order to do so, it concentrates in producing knowledge on transportation issues and solutions, including alternative planning and policy solutions. Moreover it organises debates with civic society and planning authorities and supports, with statements or presence of their member, demonstrations and residents' demands.

The work of the Mobility Forum addresses mobility issues in more specific terms with respect to the Forum de Lutas. The Mobility Forum has a long story of contesting the politics of mobility in the region, criticising the lack of planning, corruption and misplaced investments and explicitly claiming for the right to mobility. As a team of experts connected with citizens, they support, through advocacy planning (Davidoff 1965) and beyond, different mobility struggles. For example, they contested the way the new metro Line 4 was planned as a unique line instead of a network, the prioritization of cable car construction over health services in favelas, and new BRT corridors implemented in areas that have demand for much higher capacity systems (Verlinghieri 2016). In specific terms, the Mobility Forum is strongly concentrated in advocating for greater investments in rail transport, criticising the road mobility planning culture that generates exclusion and unsustainable mobilities and finances the oligopoly of bus companies. For the Mobility Forum the right to mobility can be guaranteed only having better rail public transport services. Moreover, the Mobility Forum advocates for a more open participatory transport planning strategy and actively works towards enhancing the possibility for the public to shape the politics of mobility. 
The Mobility Forum is never a monolithic entity: the single issues on which specific members are concentrated are interlinked as part of a more general strategic goal and common vision that is guaranteeing the right to mobility. This is defined in an internal document as "a fundamental right that directly affects all the basic activities of citizenship": the right to mobility, for the Mobility Forum, is necessary to access the full right to citizenship. More specifically, the Mobility Forum advocates for the right to a certain type of mobility: a sustainable and just mobility, based on a transport system in which rail transport is the main mode. The Mobility Forum, as the same document reports, considers rail transport as "always more economic and just".

The question is, right to mobility for whom? At a first look the action of the Mobility Forum appears to be completely trans-class and concentrated into advocating for a generic right to mobility for all. For example, within the Mobility Forum there are engineers supporting residents from richer neighbours to oppose the construction of a metro station in a public square (Ortiz 2012), whilst others work with residents of favelas to oppose the construction of a cable car (Freitas 2013). However, at a closer look at the causes that the Mobility Forum pursues as a complex, heterogeneous group, emerges a coherent unitary and more elaborated framing.

On one hand, with its focus on rail transport and especially on improvements to the Metro system, the Mobility Forum might seem to advocate mostly for a middle-class public concerned with the quality of public transport, but still able to access private transport or travel on the more expensive services (Pires 2013). In Rio de Janeiro, there is indeed a historical income separation in terms of transport means preference (Silva Cruz 2010; Pires 2013): the higher income groups living in the richest neighbourhoods are the ones demanding more investment in the Metro (that serves only few neighbourhoods in the metropolitan district), whilst the lower income groups, especially residents of the West zone, demand improvement in the suburban trains and on the bus services. These differential preferences are evident also in the data on car ownership and preference for car mobility, which is highly biased towards higher income groups (Motta 2002; Legroux 2014).

On the other hand, the Mobility Forum built alliances with the MPL and other USMs involved in the 2013 mobilizations, considering the issues of bus users and producing research material to support the idea of a free fare, recognising the importance of a low price and high quality public transport service for lower income groups. In an internal document the Mobility Forum considers USMs "perfectly aligned with the most unique struggles of the Mobility Forum, in opposing the institutional favouritism to entrepreneurs who form the oligopoly that dominates the privatized mobility market in the metropolitan area".

As such, the aforementioned focus that the Mobility Forum has on rail transport can be interpreted not as a way to preserve the right to mobility for the middle class, but as a demand for an ideal situation in which all the population would be able to move using rail transport, in a situation of sustainable and just mobility. In this way it can provide an answer to the problem of the bus oligopoly and to environmental issues. Despite not having an always explicit political stand in advocacy of solely lower income groups or minorities, the Mobility Forum supports the construction of a sustainable and just transport system that would more likely take into account the needs of lower income groups.

\section{Towards a right to mobility: insights from Rio de Janeiro}

In this paper we understood contested cities as fragmented urban projects, in which various actors struggle to affirm their idea and project of city and citizenship (Holston 1998, 2008, 2009; Harvey 2012). It is an urban of multiple contrasting histories, shaped by processes of neoliberalization of economies and planning regulations, and of commodification of public spaces (Harvey 1985, 2001) with often dramatic impacts over the poor and marginalised. Contestation is a practice of questioning this project and struggling for affirming an alternative one, centred on solving social and environmental inequalities (Della Porta and Diani 2006; Harvey 2012). Contested mobilities belong to this practice of questioning. Contested mobilities are then 
contested movements, meanings and practices (Cresswell and Uteng 2008) that reflect the effects of the unfolding of an unequal urban project. They also present specific traits of being mobilities in the urban space and form part of the spatial conflicts for the access to the city. In here contested mobilities take the form of conflicts for public transport investments, for implementation and use of infrastructures and for priority among different transport means and are often highly shaped by the work of USMs (Vasconcellos 2001).

The two actors presented in this paper play a main role in this contestation and in framing it around the idea of the right to mobility. In Rio de Janeiro, they operate in a context of intense mobilization and lively public debate on mobility and transport planning. The Forum de Lutas and the Mobility Forum are part of a chorus of activists and activist planners that reclaim the right to mobility both in its substantial terms of infrastructures, investments and policies, and in procedural terms, asking for being heard and have a say in the decision making processes (Purcell 2002; Soja 2010; Attoh 2012). As part of this chorus they mutually support each other. The Forum de Lutas, at the forefront of the street mobilizations, has a crucial role in claiming the right to participation, building the necessary critical mass to support the cry for the right to mobility and stop the ticket increase. At the same time, the knowledge production efforts of the Mobility Forum support with substantial information the street mobilizations. The work of the Mobility Forum is an important example of the value of giving instruments and data to support contestation (Rao et al 2000; The Autonomous Geographies Collective 2010; Verlinghieri 2016). The two forums both overlap in functions and facilitate mutual work. The need for these actors to enhance this exchange and co-production has been highly evident for us when, during our action research process, we co-organized with them an open debate in which members of the two forums met (Grupo Popular Pesquisa em Ação 2014).

More than supporting each other, the two forums also share similar aspects. Firstly, they concentrate on similar themes, both aiming to address, with different tactics, the lack of right to mobility in the region. This lack is symbolised by the high public transport fares and the planning of new infrastructures not able to support the demands of transport excluded. Secondly, both forums, as activist planners (Sager 2016), challenge existing policies and propose alternatives based on a grounded knowledge of the needs of the population. Thirdly, they are both structured as forum, composing networks of different actors (Della Porta and Diani 2006; Castells 2012), knowledges and abilities needed when dealing with a theme such as mobility that is "dynamic, changeable subject, mutant, that during the debate of ideas, will always be subject to new concepts and conclusions" (Fórum Permanente 2011). Forums provide both moments and spaces of discussion and can become insurgent planning actors (Miraftab 2009), working towards building abilities and knowledges to shape the politics of mobility. As such we have shown the importance of the right to mobility as concept able to bring together different actors with different starting agendas as part of forums and connections between the forums.

However, differences have to be noticed, not only in the types of activities the forums perform and in the forms of contestations they embrace, but also in the ways in which they use the right to mobility. The Forum de Lutas, synthesizing in a common vision all the understandings by the groups that compose it, sees in the right to mobility a gate opened to deeper critique of the model of urban development and to the neoliberal city. As protest-oriented actor, it contests the short-term fare increase policy, working with a campaignbuilding strategy (Jasper 2014). At the same time, for the Forum de Lutas, the right to mobility and right to the city are concepts that need to be radicalized, embedded into an anti-capitalist framework and broadened, being at risk of co-optation by the State (Dagnino 2004). For the Forum de Lutas and other protest-oriented groups active in Rio de Janeiro, the right to mobility (and the right to the city) is a starting point for a deeper critique of the current social and economic system (Judensnaider et al. 2013; Maricato et al. 2013; Venturini 2016). The Forum de Lutas sees the mobility crisis as effect of the neoliberal model of development. The long-term vision of the Forum de Lutas goes far beyond a vision limited to transport and mobility, calling for an entirely new form of society in which transport modes and systems have not been defined yet (Vainer 2013b; Maricato et al 2013; Venturini 2016). 
In contrast, the Mobility Forum, with its heterogeneity, asserts the right to mobility as a concept that needs specification, becoming a claim for a precise type of mobility and planning: the right to sustainable and just mobility. For the Mobility Forum this is a right limited to specific transport-related issues. However, the Mobility Forum mobilises longer-term and more structured goals with respect to the claim for a lower bus fare by the Forum de Lutas. The long-term vision of the Mobility Forum is an ideal city in which all population is able to move using rail transport. As such, despite not having a clear political stand in advocacy of lower income groups or minorities, it supports the construction of a transport system that would most likely address their needs. This utopia, for the Mobility Forum, is reachable without having to challenge the entire model of development: in the Mobility Forum the claim for the right to mobility is not subsumed by a unified political stand or inserted into an anti-capitalist framework. For the Mobility Forum the construction of the right to mobility is a policy and planning goal reachable by modifying the politics of transport and making better use of technical knowledge.

Analysing these differences we can build learning points for USMs, academics and practitioners. Both forums show the importance of focusing on the right to mobility as a unifying call, able to bring together the public and the experts and ground a long-term vision for the future of mobility. The right to mobility as concept constitutes a framing discourse that can inform transport policy and planning. However, the examples analysed tell us that the right to mobility per se has limitations. From the Forum de Lutas we can learn the importance of considering the right to mobility as being in constant dialogue with the right to the city. Moreover, the Forum de Lutas stresses the importance of a political analysis of the mobility crisis and the need to have a radical stand in considering the processes and political frameworks in place. From the Mobility Forum we learn the importance of specifying in details the right to which type of mobility, in substantial and procedural terms, and for whom, in order to decrease the possible vagueness of a claim for a 'right to mobility' for all. Which such characterization the right to mobility, as right to sustainable and just mobility, embedded into a political understanding of mobility, can become an important tool for planning, helping practitioners and academic to individuate areas that needed intervention because of its absence or denial. Moreover, the Mobility Forum gives a lesson on the important role that practitioners and academics can play in supporting and shaping contestation to become a concrete claim for better transport futures. If the objective of practitioners and academics is truly the right to sustainable and just mobility, they can play a role into building it as composing part of the right to the city, going beyond a mere technical competence and broadening their analysis and actions to wider political and social aspects and impacts. Moreover, both forums show the importance of developing analysis and planning proposals maintaining a constant dialogue with the public and especially the population groups in need (Souza 2001a, 2006a, 2006b; Verlinghieri 2016).

In conclusion, the concept of the right to sustainable and just mobility can help bringing together heterogeneous actors, unifying campaigns and policy goals from the perspective of disadvantaged groups. At the same time, using the right to mobility in dialogue with the right to the city -as concepts referring to the possibility to physically access the city, to the ability to shape the city and the decision about its future-, can highlight the importance of mobility as key aspect to understand and overcome the urban crisis (Sheller and Urry 2006; Sheller 2008). As the two actors analysed showed, USMs can function as spaces in which to contest the lack of right to mobility and, at the same time, to practice and affirm it as the right to shape the politics of mobility and the city. USMs are spaces for insurgent participation (Hilbrandt 2016). Moreover, USMs' discourses make clear that different interpretations of the right to mobility exist, in a plurality of voices part of the richness and complexity of the term. This richness, more than creating contrasts, allows connecting struggles and makes it possible for the right to mobility to become a point of contact between different actors and perspectives. In this way it allows to "unite diverse and particularized struggle into larger and more powerful movements" (109), as, accordingly with Soja (2010), it happens with the right to the city. As also Harvey and Potter (2009) point out, the right to the city is indeed a process, continuously shaped by our desire and new challenges and built around "social solidarities" (48). In this, USMs are crucial actors, affirming the right to the city and the right to mobility in different spatial and social forms, being able to 
expand it, radicalise (Harvey and Potter 2009) and avoid co-optation (Dagnino 2004).

In this interpretation, the right to mobility and the right to the city are able to open new social paths towards more sustainable and just urban living. Most importantly, beyond an individualistic concern for freedom, USMs that claim for the right to mobility are able to build a bridge between the need to individual behavioural change and demand for mobility as a common (Harvey 2012; Clare and Habermehl 2016). If, as increasingly recognised in transport geography (Vasconcellos 2001; Banister 2008; Lucas 2013; Kwan and Schwanen 2016), there is the need for a radical shift towards more sustainable mobilities, learning from the practices and ideas of USMs around the world, can help shape such transitions.

\section{Acknowledgments}

We would like to thank the Contested Cities network for financial support during this study. We also gratefully thank Dr Brendan Doody, Rafael Pereira and our editors and our anonymous reviewers for their comments and suggestions that greatly improved the manuscript.

\section{References}

1. Aldred, R. 2013. Who are Londoners on Bikes and What do They Want? Negotiating Identity and Issue Definition in a "Pop-up" Cycle Campaign'. Journal of Transport Geography. 30, 194-201.

2. Alencar, C. 2013. A Rua, a Nação e o Sonho : Uma Reflexão para as Novas Gerações. Rio de Janeiro: Mardeideias.

3. Assis, A. 2014. Gentrifica... O QUÊ ?! Gentrificação.[Online].[Accessed 10 September 2010]. Available from: http://redesdamare.org.br/blog/noticias/gentrifica-o-que-gentrificacao/

4. Attoh, K. A. 2011. What Kind of Right Is the Right to the City? Progress in Human Geography. 35(5), 669685.

5. Attoh, K. A. 2012. The Transportation Disadvantaged and the Right to the City in Syracuse, New York. The Geographical Bulletin. 53(1), 1.

6. Avila, G. A. 2006. Mobilidade Urbana, Iniquidade e Politicas Sociais. Rio de Janeiro: IPEA.

7. Banister, D. 2008. The Sustainable Mobility Paradigm. Transport policy. 15(2), 73-80.

8. Bergmann, S. and Sager, T. eds. 2008. The Ethics of Mobilities: Rethinking Place, Exclusion, Freedom and Environment. Oxford: Ashgate.

9. Beyer, A. 2011. L'Échéance des Jeux Olympiques de 2016 et les Stratégies de Restructuration du Transport Métropolitain de Rio de Janeiro. Confins.[Online]. [Accessed 10 June 2016]. Available from:

http://confins.revues.org/7087

10. Breitbart, M. 2003. Participatory Research. In: Clifford, N. and Valentine, G. eds. Key Methods in Geography. London: Sage, 161-178.

11. Brenner, N. et al. eds. 2012. Cities for People, not for Profit: Critical Urban Theory and the Right to the City. London: Routledge.

12. Carvalho, C. H. and Pereira, R. H. M. 2012. Gastos das Famílias Brasileiras com Transporte Urbano Público e Privado no Brasil: uma Análise da POF 2003 e 2009. Texto para Discussão IPEA, No 1803. [Accessed 19 January 2016]. Available from: http://repositorio.ipea.gov.br/handle/11058/993

13. Carvalho, C. H. R. de and Pereira, R. H. M. 2011. Efeitos da Variação da Tarifa e da Renda da População Sobre a Demanda de Transporte Público Coletivo Urbano no Brasil (Texto para Discussão (TD) No. 1595). Brasília, DF: Instituto de Pesquisa Econômica Aplicada - IPEA. [Accessed 19 January 2016]. Available from: http://repositorio.ipea.gov.br/handle/11058/1282

14. Castells, M. 1977. The Urban Question: A Marxist Approach. Edward Arnold: London.

15. Castells, M. 1983. The City and the Grassroots: a Cross-cultural Theory of Urban Social Movements. London: Edward Arnold. 
16. Castells, M. 2012. Networks of Outrage and Hope: Social Movements in the Internet Age. Cambridge: Polity Press.

17. Cava, B. 2013. A Multidão Foi ao Deserto: As Manifestações no Brasil em 2013 (Jun. a Out.). Rio de Janeiro: Annablume.

18. Cava, B. and Cocco, G. eds. 2014. Amanhã Vai Ser Maior: O Levante da Multidão no Ano que Não Terminou. Rio de Janeiro: Annablume.

19. Chakrabarty, D. 2008. Provincializing Europe: Postcolonial Thought and Historical Difference: Postcolonial Thought and Historical Difference. Princeton: Princeton University Press.

20. Clifford, N. and Valentine, G. eds. 2003. Key Methods in Geography. London: Sage.

21. Clube de Engenharia, 2014. Fórum em Luta pela Mobilidade Urbana no Rio. 30 January. Clube de Engenharia. [Online]. [Accessed 19 January 2016]. Available from:

http://www.portalclubedeengenharia.org.br/info/forum-em-luta-pela-mobilidade-urbana-no-rio

22. Coghlan, D. and Brannick, T. 2005. Doing Action Research in Your Own Organization. Thousand Oaks: Sage.

23. Comitê Popular da Copa e Olimpíadas do Rio de Janeiro. 2012. Megaeventos e Violações dos Direitos Humanos no Rio de Janeiro. Rio de Janeiro.

24. Comitê Popular da Copa e Olimpíadas do Rio de Janeiro. 2013. Megaeventos e Violações dos Direitos Humanos no Rio de Janeiro. Rio de Janeiro.

25. Comitê Popular da Copa e Olimpíadas do Rio de Janeiro. 2014. Megaeventos e Violações dos Direitos Humanos no Rio de Janeiro. Rio de Janeiro.

26. Comitê Popular da Copa e Olimpíadas do Rio de Janeiro. 2015. Dossiê sobre as Violações do Direito ao Esporte e à Cidade. Rio de Janeiro.

27. Comitê Popular da Copa e Olimpíadas do Rio de Janeiro. 2016. Megaeventos e Violações dos Direitos Humanos no Rio de Janeiro. Rio de Janeiro.

28. Costa, R. G. R., da Silva, C. G. T. and Cohen, S. C. 2013. A Origem do Caos : A Crise de Mobilidade no Rio de Janeiro e a Ameaça à Saúde Urbana. Cadernos Metrópole. 15(30), 411-431.

29. CPI dos Ônibus. nd. O porquê da CPI dos Onibus. CPI dos Ônibus. [Online]. [Accessed 19 June 2016]. Available from: http://cpidosonibus.com.br/site/o-porque-da-cpi.html

30. Cresswell, T. 2006. The Right to Mobility: the Production of Mobility in the Courtroom. Antipode. 38(4), 735-754.

31. Cresswell, T. and Uteng, T.P. 2008. Gendered Mobilities: towards an Holistic Understanding. In: Uteng, T.P. and Cresswell, T. eds. Gendered mobilities. Aldershot: Ashgate, 1-12.

32. Dagnino, E. 2004. Sociedade Civil, Participação e Cidadania: de que Estamos Falando?. In: Daniel, M. ed. Políticas de Ciudadanía y Sociedad Civil en Tiempos de Globalización. Caracas: Universidad Central de Venezuela, 95-110.

33. Daniel, M. ed. 2004. Políticas de Ciudadanía y Sociedad Civil en Tiempos de Globalización. Caracas: Universidad Central de Venezuela.

34. Davidoff, P. 1965. Advocacy and Pluralism in Planning. Journal of the American Institute of Planners. 31(4), 331-338.

35. Della Porta, D. and Diani, M. 2006. Social Movements: An Introduction. Malden: Blackwell Publishing.

36. DeVerteuil, G. and Golubchikov, O., 2016. Can Resilience be Redeemed? Resilience as a Metaphor for Change, not Against Change. City. 20(1), 143-151.

37. Dörrbecker, M. 2016. Public Transport Map of Rio de Janeiro. Wikimedia Commons. [Online]. [Accessed 10 September 2016]. Available from:

https://commons.wikimedia.org/wiki/File:Public_transport_map_of_Rio_de_Janeiro.png

38. Fals-Borda, O. and Rahman, M. A. eds. 1991. Action and Knowledge: Breaking the Monopoly with Participatory Action Research. New York: The Apex Press.

39. Fernandes, E. and Freitas Roseno, R. 2013. Protesta Brasil: das Redes Sociais às Manifestações de Rua. São Paulo: Prata Editora.

40. Ferreira, A. and Batey, P. 2007. Re-thinking Accessibility Planning : A Multi-layer Conceptual Framework and its Policy Implications. Town Planning Review. 78(4), 429-458. 
41. Fonseca, G. 2016. Mobilidade Urbana em Discussão. 5 January. Diario do Rio. [Online]. [Accessed 19 January 2016]. Available from: diariodorio.com/mobilidade-urbana-em-discussao/

42. Fórum Permanente da Mobilidade Urbana na Região Metropolitana do Rio de Janeiro. 2011. Manifesto. [Online]. [Accessed 19 January 2016]. Available from: http://www.mobilidadeurbanarj.org.br/

43. Freeman, J. 2012. Neoliberal Accumulation Strategies and the Visible Hand of Police Pacification in Rio de Janeiro. Revista de Estudos Universitários. 38(1), 95-126.

44. Freitas, C. 2013. Rocinha e Alemão Pretendem Processar Estado por causa de Teleférico. 29 September. Jornal do Brasil. [Online]. [Accessed 19 January 2016]. Available from: http://www.jb.com.br/rio/noticias/2013/09/29/rocinha-e-alemao-pretendem-processar-estado-por-causa-deteleferico/

45. Friendly, A. 2013. The Right to the City: Theory and Practice in Brazil. Planning Theory and Practice. 14(2), 158-179.

46. Fundação CIDE [no date]. Metropolitan Region Map, Rio de Janeiro State, Brazil. [Online]. [Accessed 10 September 2016]. Available from:

http://www.zonu.com/brazil_maps/Metropolitan_Region_Map_Rio_Janeiro_State_Brazil.htm

47. Gaffney, C. 2010. Mega-Events and Socio-Spatial Dynamics in Rio de Janeiro, 1919-2016. Journal of Latin American Geography. 9(1), 7-29.

48. Geels, F.W. 2010. Ontologies, Socio-technical Transitions (to Sustainability), and the Multi-level Perspective. Research policy. 39(4), 495-510.

49. González, S. 2011. Bilbao and Barcelona 'in Motion': How Urban Regeneration 'Models' Travel and Mutate in the Global Flows of Policy Tourism. Urban Studies. 48(7), 1397-1418.

50. González, S. 2016. Looking Comparatively at Displacement and Resistance to Gentrification in Latin American Cities. Urban Geography. 37(8), 1245-1252.

51. Grupo Popular Pesquisa em Ação 2014. Audio deo Bebate sobre o Transporte. 6 March. Grupo Popular Pesquisa em Acao - Rio de Janeiro. [Online]. [Accessed 19 January 2016]. Available from: https://pesquisaemacao.noblogs.org/post/2014/03/06/audio-do-debate-sobre-o-transporte/

52. Habermehl, V and Clare, N. 2016. Towards a Theory of 'Commonisation': An Anarchist Approach to Territory. In: Souza, M.L. de, White, R.J. and Springer, S. eds. 2016. Theories of Resistance: Anarchism, Geography, and the Spirit of Revolt. London: Pickering \& Chatto Publishers .

53. Hague, E. 2010. 'The Right to Enter Every Other State'-the Supreme Court and African American Mobility in the United States. Mobilities. 5(3), 331-347.

54. Hall, C. M. 1992. Hallmark Tourist Events: Impacts, Management and Planning. London: Bellhaven.

55. Hall, C. M. 2006. Urban Entrepreneurship, Corporate Interests and Sports Mega-Events: The Thin Policies of Competitiveness within the Hard Outcomes of Neoliberalism. The Sociological Review. (54), 59-70.

56. Hamel, P. et al. eds. 2000. Urban Movements in a Globalising World. London: Routledge.

57. Hannam, K. Sheller, M. and Urry, J. 2006. Editorial: Mobilities, Immobilities and Moorings. Mobilities. $1(1), 1-22$.

58. Harvey, D. 1985. The Urbanization of Capital: Studies in the History and Theory of Capitalist Urbanization. Baltimore: John Hopkins University Press.

59. Harvey, D. 1989. The Condition of Postmodernity. Oxford: Blackwell.

60. Harvey, D. 2001. Spaces of Capital: Towards a Critical Geography. Edinburgh: Edinburgh University Press.

61. Harvey, D. 2008. The Right to the City. New Left Review. (53), 23-40.

62. Harvey, D. 2012. Rebel Cities: From the Right to the City to the Urban Revolution. London: Verso Books.

63. Harvey, D. and Potter, C. 2009. The Right to the Just City. In: Marcuse, P. et al. eds. Searching for the Just City: Debates in Urban Theory and Practice. New York: Routledge, 40-51.

64. Hickman, R. and Banister, D. 2014. Transport, Climate Change and the City. London and New York: Routledge.

65. Hilbrandt, H. 2016. Insurgent Participation Consensus and Contestation in Planning the Redevelopment of Berlin Tempelhof Airport. Urban Geography. 38(4), 1-20.

66. Holston, J. 1998. Spaces of Insurgent Citizenship. In: Sandercock, L. ed. Making the Invisible Visible: A Multicultural Planning History. Berkeley: University of California Press, 37-56. 
67. Holston, J. 2008. Insurgent Citizenship: Disjunctions of Democracy and Modernity in Brazil. Princeton: Princeton University Press.

68. Holston, J. 2009. Insurgent Citizenship in an Era of Global Urban Peripheries. City \& Society. 21(2), 245267.

69. Horton, E. P. F. D. 2006. Environmentalism and the bicycle. Environmental Politics. 15(1), 41-58.

70. IBGE. 2008. Pesquisa Nacional por Amostra de Domicílios - PNAD 2008. Rio de Janeiro: IBGE.

71. IPPUR/UFRJ 2012. Projeto Metropolização e Megaeventos: os impactos da Copa do Mundo 2014 ed as Olimpíadas 2016 Relatório Parcial Rio de Janeiro - Abril de 2012 [online]. [Accessed 10/10/2013].

Available from: http://www.observatoriodasmetropoles.net/download/Relat_RJ\%202012.pdf.

72. Jasper, J. 2014. Protest: A Cultural Introduction to Social Movements. Cambridge: Polity Press.

73. Jennings, A., Vainer, C and Rolnik, R. eds. 2014. Brasil em Jogo. São Paulo: Boitempo.

74. Jones, P. and Lucas, K. 2012. The Social Consequences of Transport Decision-Making: Clarifying Concepts, Synthesising Knowledge and Assessing Implications. Journal of Transport Geography. 21, 4-16.

75. Judensnaider, E., Piazzon, L and Ortellado, P. 2013. Vinte Centavos: A Lutas Contra o Aumento. São Paulo: Veneta.

76. Juris, J.S. and Pleyers, G.H. 2009. Alter-activism : Emerging Cultures of Participation Among Young Global Justice Activists. Journal of Youth Studies. 12(1), 57-75.

77. Kinna, R. ed. 2012. The Continuum Companion to Anarchism. London: Continuum International Publishing Group.

78. Kwan M.P. and Schwanen T. 2016. Geographies of Mobility. Annals of the American Association of Geographers. 106(2), 243-25

79. Lefebvre, H. 1968. Le Droit à la Ville. Paris: Anthopos.

80. Lefebvre, H. 1996. Writings on Cities. Oxford: Blackwell.

81. Legroux, J. 2013. Mega-events in Rio de Janeiro...And the Winners Are? Perceptions of the Impacts of Transport Policies on Socio-spatial Justice to Reveal Mega-events Contradictions. In: 13th WCTR, 15/18 July 2013, Rio de Janeiro. [Online]. [Accessed 10 December 2015]. Available from:

http://www.wctrs.leeds.ac.uk/wp/wp-content/uploads/abstracts/rio/general/2689.pdf

82. Legroux, J. 2014. From Discourse to Reality: Impacts of Rio's “Transportation Revolution” on Socio-spatial Justice. In: Ribeiro, L. C. Q. ed. The Metropolis of Rio de Janeiro: A Space in Transition. Rio de Janeiro: Letra Capital, 343-370.

83. Legroux, J. 2016. A Scolhida da Copa do Mundo 2014 e das Olimpíadas 2016 e os Impactos da "Revolução dos Transportes" sobre a Justiça Socioespacial : Mudar Tudo para que Nada Mude? PhD Thesis, Universidade Federal do Rio de Janeiro.

84. Lucas, K. 2013. Qualitative Methods in Transport Research: the 'Action Research' Approach. In: Zmud, J., Lee-Gosselin, M. and Carrasco, J.A. eds. Transport Survey Methods: Best practice for Decision Making. London: Emerald Publishing .

85. Lucas, K., Mattioli, G., Verlinghieri, E. and Guzman, A. 2016. Transport Poverty and its Adverse Social Consequences. Proceedings of the Institution of Civil Engineers: Transport. 169(6), 353-365.

86. Magalhães, L. E. and Berta, R. 2013. Apenas Quatro Empresários Concentram um Terço do Transporte Rodoviário no Rio. O Globo. [Online]. [Accessed 10 December 2015]. Available from:

http://oglobo.globo.com/rio/apenas-quatro-empresarios-concentram-um-terco-do-transporte-rodoviario-norio- 8417193

87. Marcuse, P. 2012. Whose Right(s) to What City?. In: Brenner, N. et al. eds. Cities for People, not for Profit: Critical Urban Theory and the Right to the City. London: Routledge, 24-41.

88. Marcuse, P. et al. eds. 2009. Searching for the Just City: Debates in Urban Theory and Practice. New York: Routledge.

89. Maricato, E. 2015. Para Entender a Crise Urbana. São Paulo: Expressão Popular.

90. Maricato, E. et al. eds. 2013. Cidades Rebeldes: Passe Livre e as Manifestações que Tomaram as Ruas do Brasil. São Paulo: Boitempo.

91. Mayer, M. 2000. Urban Social Movements in an Era of Globalisation. In: Hamel, P. et al. eds. Urban Movements in a Globalising World. London: Routledge, 141-157. 
92. Mayer, M. 2006. Manuel Castells' the City and the Grassroots. International Journal of Urban and Regional Research. 30(1), 202-206.

93. Mayer, M. 2012. The "Right to the City" in Urban Social Movements. In: Brenner, N. et al. eds. Cities for People, not for Profit: Critical Urban Theory and the Right to the City. London: Routledge, 63-85.

94. Mayer, M. 2013. Multiscalar Mobilization for the Just City: New Spatial Politics of Urban Movements. In: Nicholls, W. et al. Eds. Spaces of Contention: Spatialities and Social Movements. London: Ashgate, 163198.

95. McTaggart, R. ed. 1997. Participatory Action Research: International Contexts and Consequences. Albany: State University of New York Press.

96. Miraftab, F. 2009. Insurgent Planning : Situating Radical Planning in the Global South. Planning Theory. $8(1), 32-50$.

97. Motta, R. S. D. 2002. Padrão de Consumo, Distribuição de Renda e o Meio Ambiente no Brasil. (Texto para Discussão (TD) No. 856). Brasilia, DF: Instituto de Pesquisa Econômica Aplicada. [Accessed 13 September 2016]. Available from: http://www.en.ipea.gov.br/agencia/images/stories/PDFs/TDs/td_0856.pdf

98. Nobre, M. 2013. Imobilismo em Movimento. Editora Companhia das Letras.

99. OGI - SAGE/COPPE/UFRJ Research Team 2014. Initial Report to Measure the Impacts and the Legacy of the Rio 2016 Games. [Online]. [Accessed 19 January 2016]. Available from:

https://www.rio2016.com/sites/default/files/parceiros/ogi_rio_2016_r1_eng1.pdf

100. Ortiz, F. 2012. Árvores Centenárias Ameaçadas pela Construção de Metrô no Rio. 17 December. ((o))eco.

[Online]. [Accessed 19 January 2016]. Available from: http://www.oeco.org.br/noticias/26747-arvorescentenarias-ameacadas-pela-construcao-de-metro-no-rio/

101. Palladini, E. 2011. Creating More Livable Cities: the Case of the Rio de Janeiro Metropolitan Area. Washington: World Bank.

102. Paterson, M. 2007. Automobile Politics: Ecology and Cultural Political Economy. Cambridge: Cambridge University Press.

103. Pécoud, A. and De Guchteneire, P. 2006. International Migration, Border Controls and Human Rights: Assessing the Relevance of a Right to Mobility. Journal of Borderlands Studies. 21(1), 69-86.

104. Pereira, R. H. M., and Schwanen, T. 2013. Commute Time in Brazil (1992-2009): differences between metropolitan areas, by income levels and gender (Discussion Paper 1813a). Brasília, DF: Instituto de Pesquisa Econômica Aplicada - IPEA. [Accessed 10 September 2016]. Available from: http://repositorio.ipea.gov.br/handle/11058/964

105. Perlman, J. 1979. The Myth of Marginality: Urban Poverty and Politics in Rio de Janeiro. Berkeley: University of California Press.

106. Perlman, J. 2010. Favela: Four Decades of Living on the Edge in Rio de Janeiro. Oxford: Oxford University Press.

107. Pero, V. and Mihessen, V. 2013. Mobilidade Urbana e Pobreza no Rio de Janeiro. Revista Econômica. 15(2), 23-50.

108. Pickvance, C. 2003. From Urban Social Movements to Urban Movements: A review and Introduction to a Symposium on Urban Movements. International Journal of Urban and Regional Research. 27(1), 102-9.

109. Pires, L. 2013. Transportes Públicos e Representações sobre Mobilidade Social : Possíveis Percepções a partir do Rio de Janeiro e de Buenos Aires. Anuário Antropológico. 2, 165-193.

110. Pontes, E. 2013 . Exclusão Socioespacial, Acessibilidade e Mobilidade : Notas para uma Análise da Região Metropolitana do Rio de Janeiro pela ótica do Sistema de Transportes, no Contexto dos Grandes Eventos Esportivos. Chão Urbano. [Online]. [Accessed 10 September 2016]. Available from: https http://www.chaourbano.com.br/visualizarArtigo.php?id=68

111. Prefeitura do Rio. 2015. Política Habitacional do Rio, Suas Diretrizes e Números Macros. [Online]. [Accessed 10 September 2016]. Available from: https://medium.com/explicando-a-pol\%C3\%ADtica-dehabita $\% \mathrm{C} 3 \% \mathrm{~A} 7 \% \mathrm{C} 3 \% \mathrm{~A} 30$-da-prefeitura/pol\%C3\%ADtica-habitacional-do-rio-suas-diretrizes-en\%C3\%BAmeros-macros-ce687846392\#.vmzj4uoob

112. Pucher, J. and Lefèvre, C. 1996. The Urban Transport Crisis in Europe and North America. Berlin: Springer.

113. Purcell, M. 2002. Excavating Lefebvre: The Right to the City and its Urban Politics of the Inhabitant. 
GeoJournal. 58(2-3), 99-108.

114. Purcell, M. 2006. Urban Democracy and the Local Trap. Urban Studies. 43(11), 1921-194.

115. Rao, H., Morrill, C. and Zald, M.N., 2000. Power Plays: How Social Movements and Collective Action Create New Organizational Forms. Research in Organizational Behavior. 22, 237-281.

116. Rawcliffe, P. 1995. Making Inroads: Transport Policy and the British Environmental Movement. Environment. 37(3), 16-36.

117. Ribeiro, L. C. Q. ed. 2014. The Metropolis of Rio de Janeiro: A Space in Transition. Rio de Janeiro: Letra Capital.

118. Rio 2016. 2009. Transport Strategic Plan for the Rio 2016 Olympic and Paralympic Games. Rio de Janeiro: Rio 2016.

119. Rio 2016. 2014. Embracing Change : Rio 2016 Sustainability Report. Rio de Janeiro: Rio 2016.

120. Rodrigues, J.M. 2014. Urban Mobility in the "Olympic City": a Transportation Revolution in Rio de Janeiro? In: Ribeiro, L. C. Q. ed. The Metropolis of Rio de Janeiro: A Space in Transition. Rio de Janeiro: Letra Capital, 279-288.

121. Sá, T. H. de et al. (2016) 'Socioeconomic and regional differences in active transportation in Brazil', Revista de Saúde Pública, 50(0). doi: 10.1590/S1518-8787.2016050006126.

122. Sagaris, L. 2014. Citizen Participation for Sustainable Transport: The Case of "Living City" in Santiago, Chile (1997-2012). Journal of Transport Geography. (41), 74-83.

123. Sager, T. 2006. Freedom as Mobility: Implications of the Distinction between Actual and Potential Travelling. Mobilities. 1(3), 465-488.

124. Sager, T. 2016. Activist planning: a Response to the Woes of Neo-Liberalism? European Planning Studies. 24(7), 1262-1280.

125. Sandercock, L. ed. 1998. Making the Invisible Visible: A Multicultural Planning History. Berkeley: University of California Press.

126. Santos Junior, O. A. D, Queiroz Ribeiro, L. C. D. and Gaffney, C. 2015. Brasil : Os Impactos da Copa do Mundo 2014 e das Olimpíadas 2016. Rio de Janeiro: E-papers Serviços Editoriais.

127. Schuurman, F. and Van Naersen, T. eds.1989. Urban Social Movements in the Third World. New York: Routledge.

128. Schuurman, F.J. 1989. Urban Social Movements: Between Regressive Utopia and Socialist Panacea. In: Schuurman, F. and Van Naersen, T. eds. Urban Social Movements in the Third World. New York: Routledge, 9-26.

129. Schwanen, T., Banister, D and Anable, J. 2011. Scientific Research about Climate Change Mitigation in Transport: A Critical Review. Transportation Research Part A: Policy and Practice. 45(10), 993-1006.

130. Secretaria de Estado de Transportes. 2014. PDTU. [Online]. [Accessed 10 January 2017]. Available from: http://www.rio.rj.gov.br/dlstatic/10112/5333332/4139325/25PDTUGovEstado092014.pdf

131. Sheller, M. 2008. Mobility, Freedom and Public Space: The Ethics of Mobilities : Rethinking Place, Exclusion, Freedom, and Environment. In: Bergmann, S. and Sager, T. eds. The Ethics of Mobilities: Rethinking Place, Exclusion, Freedom and Environment. Oxford: Ashgate, 25-38.

132. Sheller, M. 2011. Mobility. Sociopedia.isa. [Online]. [Accessed 10 September 2016]. Available from: http://www.sagepub.net/isa/resources/pdf/mobility.pdf

133. Sheller, M. and Urry, J. 2006. The New Mobilities Paradigm. Environment and planning A. 38(2), 207-226.

134. Sheppard, E., Leitner, H. and Maringanti, A. 2013. Provincializing Global Urbanism: A Manifesto. Urban Geography, 34(7), 893-900.

135. Silva Cruz, J. D. 2010. Transporte Ferroviário Urbano em Questão : Análise das Políticas Públicas em Pauta e as Consequências para os Trabalhadores da Região Metropolitana do Rio de Janeiro. Rio de Janeiro: Departamento de Serviço Social/PUC-Rio.

136. Silva, S. and Torres, H. 2013. Traffic and Public Transport Planning for Olympic Games: Challenges for the City of Rio de Janeiro. 13th WCTR, 15-18 July 2013, Rio de Janeiro.

137. Sistema FIRJAN. 2012. Decision: Rio Investments 2012-2014. Rio de Janeiro.

138. Sistema FIRJAN. 2014. Decision: Rio Investments 2014-2016. Rio de Janeiro.

139. Smith, L.T. 2013. Decolonizing methodologies : Research and Indigenous Peoples. London: Zed Books. 
140. Soja, E. 2010. Seeking Spatial Justice. Minneapolis: University of Minnesota Press.

141. Souza, M. L. 1999. O Desafio Metropolitano. Rio de Janeiro: Bertrand Brasil.

142. Souza, M. L. 2001a. Mudar a Cidade: Uma Introdução Crítica ao Planejamento e à Gestão Urbanos. Rio de Janeiro: Bertrand Brasil.

143. Souza, M. L. 2001b. Metropolitan Deconcentration, Socio-political Fragmentation and Extended Suburbanisation: Brazilian Urbanisation in the 1980s and 1990s. Geoforum. (32), 437-447.

144. Souza, M. L. 2001c. The Brazilian Way of Conquering the "Right to the City". DISP, 37(147), 25-31.

145. Souza, M. L. 2006a. A Prisão e a Ágora: Reflexões em Torno da Democratização do Planejamento e da Gestão das Cidades. Rio de Janeiro: Bertrand Brasil.

146. Souza, M. L. 2006b. Together with the State, Despite the State, Against the State: Social Movements as 'Critical Urban Planning' Agents. City. 10(3), 327-342.

147. Souza, M. L. 2008. Fobópole: o Medo Generalizado e a Militarização da Questão Urbana. Rio de Janeiro: Bertrand Brasil.

148. Souza, M. L. 2010. Which Right to which City? In Defence of Political-Strategic Clarity. Interface. 2(1), 315-333.

149. Souza, M.L. de, White, R.J. and Springer, S. eds. 2016. Theories of Resistance: Anarchism, Geography, and the Spirit of Revolt. London: Pickering \& Chatto Publishers.

150. Tarifa Zero. 2011. Sao Paulo sem Catracas: Cartilha da Campanha Tarifa Zero. [online]. [Accessed 13 February 2014]. Available from: http://www.tarifazerosp.net/2011/08/24/cartilha-da-campanha/

151. The Autonomous Geographies Collective. 2010. Beyond Scholar Activism: Making Strategic Interventions Inside and Outside the Neoliberal University. Acme: An International E-journal for Critical Geographies. $1(2), 245-275$.

152. Tribunal de Contas do Município. 2012. Voto TCM 358/2012 - CPI dos Ônibus. [Online]. [Accessed 10 December 2015]. Available from:

http://cpidosonibus.com.br/site/images/bd_cpi/docs_tcm/contratros/7VotoTCM358_11jul2012.pdf

153. UNDP. 2010. Human Development Report 2010. Wellington: United Nation Development Programme.

154. Uteng, T.P. and Cresswell, T. eds. 2008. Gendered mobilities. Aldershot: Ashgate.

155. Vainer, C. 2000a. Pátria, Empresa e Mercadoria. Notas Sobre a Estratégia Discursiva do Planejamento Estratégico Urbano. In: Arantes, O. B. F., Vainer, C. and Maricato, E. eds. A Cidade do Pensamento Único: Desmanchando Consensos. Rio de Janeiro: Editora Vozes, 75- 103.

156. Vainer, C. 2000b. Os Liberais Também Fazem Planejamento Urbano?. In: Arantes, O. B. F. et al. eds. A Cidade do Pensamento Único: Desmanchando Consensos. Rio de Janeiro: Editora Vozes, 105-119.

157. Vainer, C. 2013a. Cidade de Exceção: Reflexões a partir do Rio de Janeiro. Anais: Encontros Nacionais da ANPUR. [Online]. 14. [Accessed 10 September 2016]. Available from:

http://unuhospedagem.com.br/revista/rbeur/index.php/anais/article/view/2874/2811

158. Vainer, C. 2013b. Mega-eventos, Mega-negócios, Mega-protestos: Uma Contribuição ao Debate sobre as Grandes Manifestações e as Perspectivas Políticas. [Online]. [Accessed 10 July 2017]. Available from: http://www.ettern.ippur.ufrj.br/ultimas-noticias/196/mega-eventos-mega-negocios-mega-protestos

159. Vasconcellos, E. A. 2001. Urban Transport Environment and Equity: The Case for Developing Countries. London: Routledge.

160. Vasconcellos, E.A. 2014. Políticas de Transporte No Brasil - A Construção da Mobilidade Excludente. Sao Paulo: Manole Editora.

161. Venturini, F. 2016. A Critical Perspective on Social Ecology and Urban Crises: Learning about, with and from Urban Social Movements in Rio de Janeiro. PhD Thesis. University of Leeds.

162. Verlinghieri, E. 2016. Planning for Resourcefulness: Exploring New Frontiers for Participatory Transport Planning Theory and Practice in Rio de Janeiro and L'Aquila. PhD thesis. University of Leeds.

163. Vigar, G. 2013. The Politics of Mobility: Transport Planning, the Environment and Public Policy. London: Routledge.

164. Vradis, A. 2012. Intervention - The Right against the City. AntipodeFoundation.org. [Online]. [Accessed 10 January 2016]. Available from: http://antipodefoundation.org/2012/10/01/intervention-the-right-against-thecity/ 
165. Wellman, C. H. and Cole, P. 2011. Debating the Ethics of Immigration: Is there a Right to Exclude? Oxford: Oxford University Press.

166. Zibechi, R. 2012. Territories in Resistance. Oakland: AK Press.

167. Zmud, J., Lee-Gosselin, M. and Carrasco, J.A. eds. 2013. Transport Survey Methods: Best practice for Decision Making. London: Emerald Publishing . 


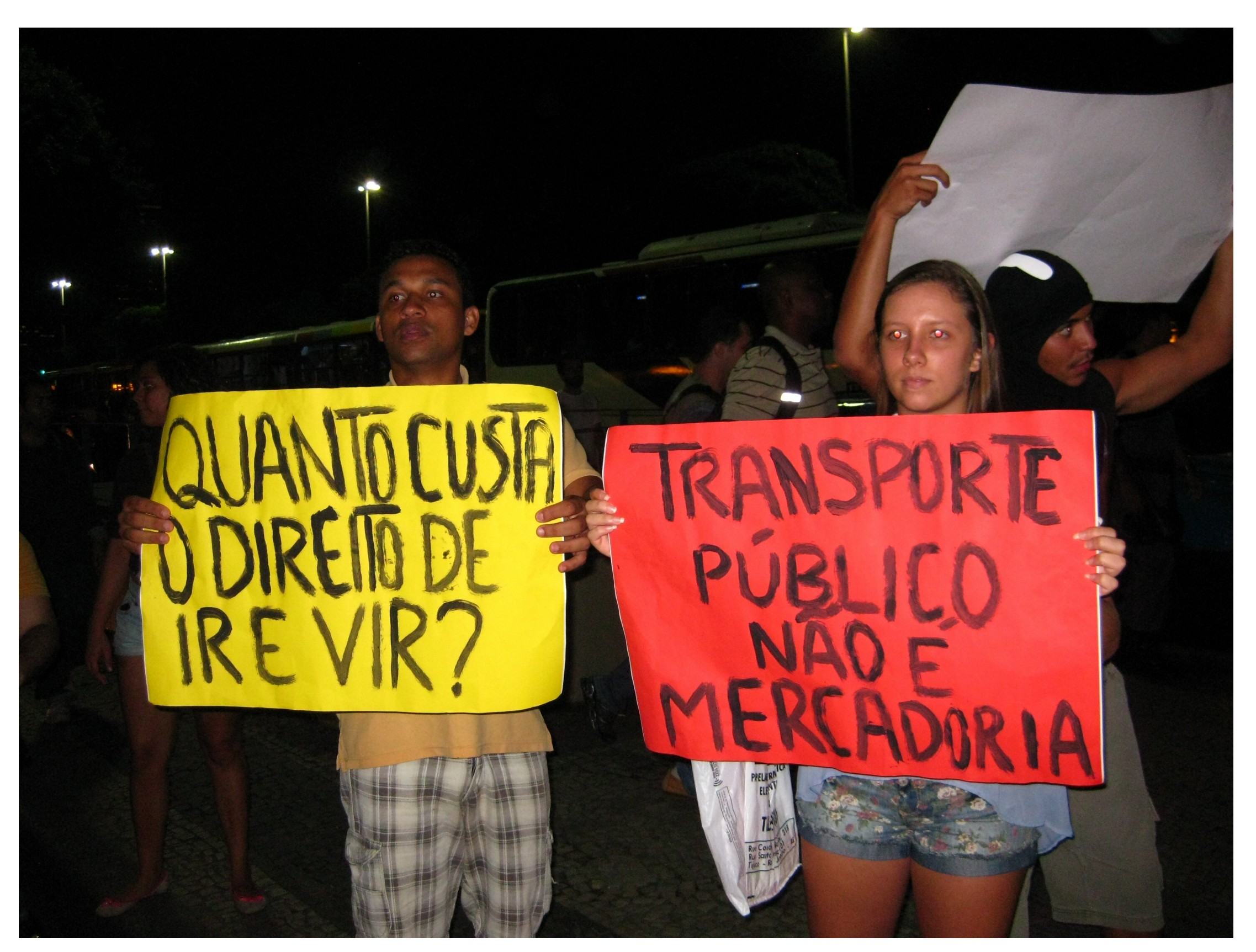



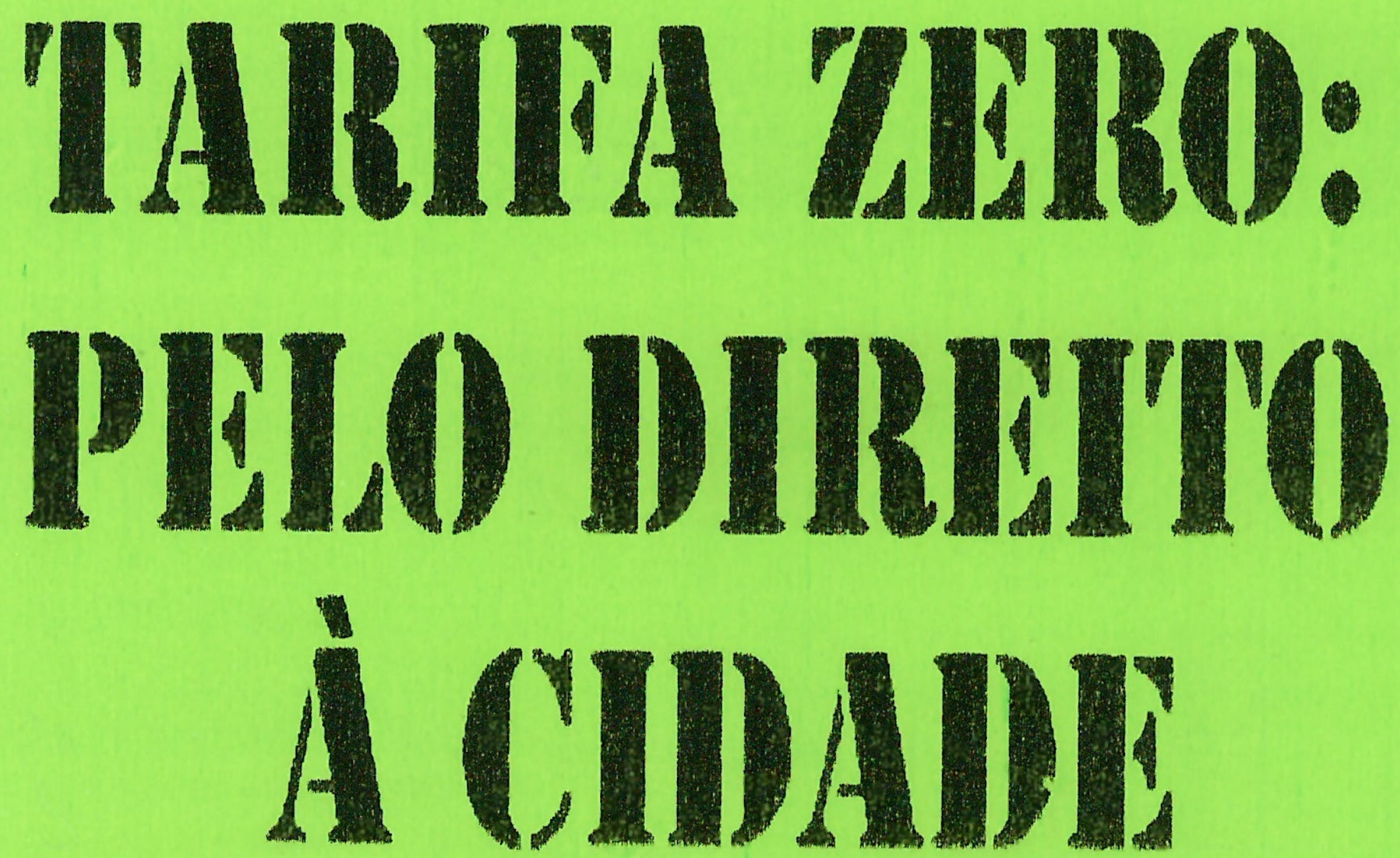


\begin{tabular}{|l|l|l|}
\hline Pressure Group & Focus/thematic & $\begin{array}{l}\text { Means of } \\
\text { pressure/communication }\end{array}$ \\
\hline $\begin{array}{l}\text { Project Clean Games inside } \\
\text { and outside the stadium } \\
\text { Project }\end{array}$ & Financial transparency & $\begin{array}{l}\text { Online tool to monitor } \\
\text { investments }\end{array}$ \\
\hline $\begin{array}{l}\text { Popular committee Rio World } \\
\text { Cup and Olympics }\end{array}$ & $\begin{array}{l}\text { Arbitrary actions of the } \\
\text { municipality or state or federal } \\
\text { governments }\end{array}$ & $\begin{array}{l}\text { Published Documents (Comitê } \\
\text { Popular 2012-2016) }\end{array}$ \\
\hline Metropolis Observatory & $\begin{array}{l}\text { Impacts of the World Cup and } \\
\text { the Olympic Games }\end{array}$ & $\begin{array}{l}\text { Publication of documents and } \\
\text { national reports }\end{array}$ \\
\hline NGO Athletes for Brazil & $\begin{array}{l}\text { Improvement and } \\
\text { transparency of the national } \\
\text { sport system }\end{array}$ & $\begin{array}{l}\text { Dialogue with Ministries. } \\
\text { Publication of a Manifesto }\end{array}$ \\
\hline
\end{tabular}

